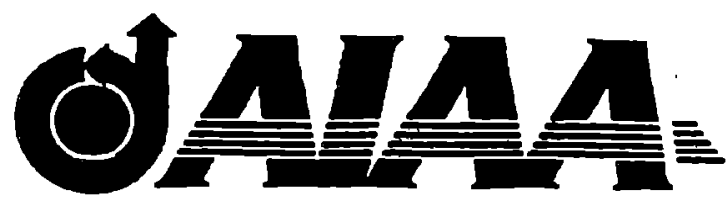

\title{
AIAA 99-0321
}

FLAME/STRETCH INTERACTIONS

OF HEAVY-HYDROCARBON/O/N

PREMIXED FLAMES

O. C. Kwon, M. I. Hassan and G. M. Faeth

Department of Aerospace Engineering

The University of Michigan

Ann Arbor, MI

\section{7th AIAA Aerospace Sciences Meeting and Exhibit January 11-14, 1999\% Reno, NV}




\title{
FLAME/STRETCH INTERACTIONS OF HEAVY-HYDROCARBON/O/N PREMIXED FLAMES
}

\author{
O.C. Kwon, M.I. Hassan ${ }^{\dagger}$ and G.M. Faeth" \\ Department of Aerospace Engineering \\ The University of Michigan \\ Ann Arbor, Michigan 48109-2140
}

\begin{abstract}
Fundamental unstretched laminar burning velocities, and flame response to stretch as characterized by Markstein numbers, were measured for premixed laminar flames involving mixtures of hydrocarbon vapors, oxygen and nitrogen. The measurements were carried out using outwardly-propagating spherical laminar premixed flames. Experimental conditions consisted of vapors of several typical liquid fuels (nhexane, n-heptane, iso-octane, methyl-alcohol and ethyl-alcohol), concentrations of oxygen in the non-fuel gases of $19-33 \%$ by volume, pressures of $0.5-2.0 \mathrm{~atm}$., fuel-equivalence ratios of $0.80-1.60$ and reactant mixture temperatures of $298 \pm 5 \mathrm{~K}$. The present flames were very sensitive to flame stretch, yielding ratios of unstretched to stretched laminar burning velocities in the range 0.4-4.0 for levels of flame stretch well below quenching conditions, e.g., for Karlovitz numbers less than 0.2. At low pressures, the present hydrocarbon vapor flames had positive Markstein numbers at fuellean conditions which is consistent with classical preferential-diffusion ideas. Increasing pressures, however, reduced Markstein numbers and progressively decreased the fuel-equivalence ratio range where Markstein numbers were positive. Negative Markstein numbers were associated with the presence of preferential-diffusion instability as evidenced by the appearance of chaotically-distorted (wrinkled) flame surfaces early during the flame propagation process.

\section{Nomenclature}

"Graduate Student Research Assistant, Department of Aerospace Engineering.

'Visiting Scholar, Department of Aerospace

Engineering; currently with the Mechanical Power

Department, Helwan University, Cairo, Egypt.

${ }^{\ddagger}$ Professor, Department of Aerospace Engineering,

Fellow AIAA.

Copyright (C 1999 by G. M. Faeth. Published by the American Institute of Aeronautics and Astronautics, Inc., with permission.
\end{abstract}

$\mathrm{D} \quad=\quad$ mass diffusivity

$\mathrm{K}=$ flame stretch or normalized increase of

flame surface area, Eq. (3)

$\mathrm{Ka}=$ Karlovitz number, $\mathrm{KD}_{\mathrm{u}} / \mathrm{S}_{\mathrm{L}}{ }^{2}$

$\mathrm{L}=$ Markstein length

$\mathrm{Ma}=$ Markstein number, $\mathrm{L} / \delta_{\mathrm{D}}$

$\mathbf{P} \quad=$ pressure

If $\quad=$ flame radius

$\mathrm{S}_{\mathrm{L}} \quad=\quad$ laminar burning velocity based on unburned gas properties

$\mathrm{S}_{\mathrm{L}^{\prime}} \quad=\quad$ value of $\mathrm{S}_{\mathrm{L}}$ at the largest radius

observed

t $=$ time

$\mathrm{T}=$ temperature

$\delta_{\mathrm{D}}=$ characteristic flame thickness, $\mathrm{D}_{\mathcal{V}} / \mathrm{S}_{\mathrm{L}}$

$\rho \quad=$ density

$\phi \quad=\quad$ fuel-equivalence ratio

Subscripts

b $=$ burned gas

$\max =$ maximum observed value

u $\quad=$ unburned gas

$\infty \quad=\quad$ unstretched flame condition

\section{Intreduction}

Several recent studies have shown that effects of preferential diffusion of mass and heat cause laminar premixed flames to be sensitive to flame stretch. ${ }^{1-10}$ Most of these studies considered gaseous fuels (e.g., hydrogen, wet carbon monoxide, methane, ethane, ethylene, propane, etc.) which raises questions about the corresponding behavior of premixed flames fueled with the vapors of liquid fuels that are important for many practical applications, e.g., aerospace and ground transportation systems, among others. Thus, the objective of the present investigation was to study premixed-flame/stretch interactions of flames fueled with the vapors of some typical liquid fuels (n-hexane, nheptane, iso-octane, methyl alcohol and ethyl alcohol) in oxygen and nitrogen mixtures. The experiments involved observations of outwardly-propagating spherical laminar premixed flames to find the fundamental laminar burning velocities of unstretched 
flames and the sensitivity of laminar burning velocities to flame strctch as characterized by Markstein numbers. Experimental conditions included non-fuel gases consisting of oxygen/nitrogen mixtures with concentrations of oxygen of $19-33 \%$ by volume, pressures of 0.5-2.0 atm., fuel-equivalence ratios of 0.80-1.60 and reactant mixture temperatures of $298 \pm$ $5 \mathrm{~K}$. The following description of the study is brief, see Refs. 4-9 and references cited therein for more details about experimental methods.

The present experiments were analyzed to find preferential-diffusion/stretch interactions similar to the earlier studies of outwardly-propagating spherical laminar premixed flames described in Refs. 4-9. As before, problems of flame thickness variations, curvature and unsteadiness caused by variations in laminar burning velocities with increasing flame radius were minimized during data reduction by only considering conditions where $\delta_{\mathrm{D}} / \mathrm{r}_{\mathrm{f}} \ll<1$ and effects of ignition disturbances and radiative heat losses are small. ${ }^{5,7}$ At such conditions, the relationship between the laminar burning velocity and flame stretch can be represented conveniently by combining an early proposal of Markstein" and the "local conditions" hypotheses of Kwon et al., ${ }^{4}$ to yield:

$$
\mathrm{S}_{\mathrm{L}_{-}} / \mathrm{S}_{\mathrm{L}}=1+\mathrm{MaKa}
$$

where the dimensionless Karlovitz, Ka, and Markstein, $\mathrm{Ma}$, numbers characterize flame stretch, and the response of the flame to stretch, respectively. The values of $S_{L}$ and $K a$ were found following Strehlow and Savage, ${ }^{12}$ based on predicted burned gas properties found using the computer codes of McBride et al. ${ }^{13}$ and Reynolds, ${ }^{14}$ as described later.

Several other proposals have been made to represent effects of flame stretch on laminar burning velocities, see Refs. 1,2 and 10 and references cited therein; nevertheless, Eq. (1) is particularly convenient because $\mathrm{Ma}$ has proven to be relatively constant for wide ranges of $\mathrm{Ka}$. Thus, $\mathrm{S}_{\mathrm{L}_{-}}$and Ma provide concise measures of premixed flame propagation rates and response to stretch that will be used to summarize the findings of the present investigation. The small stretch limit of Eq. (1) is also of interest, in order to connect present results to classical asymptotic theories of laminar premixed flame propagation; this expression can be found from Eq. (1) as follows:'

$$
\mathrm{S}_{\mathrm{V}} / \mathrm{S}_{\mathrm{L}_{-}}=1-\mathrm{Ma} \mathrm{Ka}_{-}, \mathrm{Ka}_{-} \ll 1
$$

2 where $\mathrm{Ma}_{-} \approx \mathrm{Ma}$ has been observed for relatively wide ranges of $\mathrm{Ka}$ as noted earlier. Other advantages of the present characterization of premixed-flame/stretch interactions can be summarized as follows: ${ }^{7}$ data reduction is direct and does not involve the use of flame structure models that are difficult to fully define and are likely to be revised in the future, the characterization is concise which facilitates its use by others, the positive and negative ranges of Ma provide a direct indication of stable and unstable flame surface conditions with respect to effects of preferential diffusion, and the results can be readily transformed to provide direct comparisons with other ways to characterize premixed-flame/stretch interactions. It should be noted, however, that the present approach has only been applied to outwardlypropagating spherical laminar premixed flames when $\delta_{\mathrm{D}} / \mathrm{r}_{\mathrm{f}}$, effects of ignition disturbances and effects of radiation are small. Thus, direct use of the present $\mathrm{Ma}$ to characterize effects of flame stretch for other circumstances should be approached with caution.

The properties of the laminar burning velocities of premixed liquid-fuel-vapor/air mixtures for the present liquid fuels have been considered during several previous investigations, see Refs. 10, 15-29 and references cited therein. Table 1 is a summary of the main features of these studies, including: the experimental method and the ranges of unburned mixture pressures, fuel-equivalence ratios, concentrations of oxygen in the non-fuel gas and temperatures. Studies where laminar buming velocities were corrected for stretch, and where premixedflame/stretch interactions were found by reporting Markstein lengths or numbers, are also noted.

Bradley et al. $^{10}$ studied outwardly-propagating laminar premixed flames, finding unstretched laminar burning velocities and Markstein numbers for mixtures of air and vapors of iso-octane and iso-octane/n-heptane blends. Their methods of data reduction differed from methods used here and in earlier related studies, ${ }^{4-9}$ but their results do suggest strong response to stretch for reactant mixtures fueled with hydrocarbon vapors. Independent confirmation of these results and consideration of other fuel vapors, however, clearly is needed due to the importance of these findings.

Law and coworkers ${ }^{27-29}$ also considered effects of stretch on laminar burning velocities. They measured laminar burning velocities for flames involving isooctane, methyl-alcohol and ethyl-alcohol vapors while employing the counterflow twin flame technique. Measurements at finite stretch rates were extrapolated using an empirical technique in order to find the fundamental laminar buming velocities of unstretched 
flames. Flame response to stretch, however, was not quantified during these studies.

The other experimental studies summarized in Table l use a variety of techniques but do not consider effects of stretch. Thus, the laminar burning velocities that are reported involve considerable uncertainties about effects of stretch, particularly in view of the strong premixed-flame/stretch sensitivity observed for fiel vapor/air flames by Bradley et al. ${ }^{10}$

Due to the importance of premixed flames involving liquid-hydrocarbon-vapor/air mixtures, numerical simulations of such flames have received considerable attention. Studies along these lines, limited to detailed reaction mechanisms for experimental conditions considered during the present investigation, include Bradley et al. ${ }^{26}$ Law and coworkers, ${ }^{27-29}$ Wannatz and coworkers, ${ }^{30,32}$ Lindstedt and Maurice, ${ }^{31}$ Peters and coworkers, ${ }^{33,35}$ and Held et al. $^{34}$ The main features of these simulations are summarized in Table 2, including: the reactant mixtures considered, the numbers of species and reactions included in the chemical mechanism, and the initial temperature and pressure of the reactants. Calculations using these detailed mechanisms are limited to the laminar burning velocities of unstretched flames. Law and coworkers ${ }^{27-29}$ and Müller et al. ${ }^{35}$ use corresponding stretch-corrected unstretched laminar burning velocities to evaluate their predictions. The remaining studies, however, compare predictions with measurements of laminar buming velocities having unknown effects of stretch which somewhat compromises the evaluation. Numerical simulations of premixed-flame/stretch interactions using detailed mechanisms require lengthy computation times and none have yet been reported for the conditions considered during the present investigation. Müller et al., ${ }^{35}$ however, obtained predictions of premixedflame/stretch interactions for iso-octane-fueled flames using a simplified approach that suggests rather strong sensitivity to stretch, in qualitative agreement with the measurements of Bradley et al. ${ }^{10}$

Review of past work suggests that new measurements of unstretched laminar burning velocities and premixed-flame/stretch interactions are needed for reactant mixtures fueled with vapors of liquidhydrocarbons. Thus, the present investigation had the following objectives: (1) to measure the properties of outwardly-propagating spherical laminar premixed flames of liquid-hydrocarbon-vapor/O/N mixtures at various pressures and standard temperature (298K), (2) to reduce the measurements to find characteristic laminar premixed flame properties $\left(\mathrm{S}_{L_{-}}\right.$and $\left.\mathrm{Ma}\right),(3)$ to compare the new measurements with existing measurements and numerical simulations as summarized in Tables 1 and 2, and (4) to exploit the new measurements to gain insight about premixedflame/stretch interactions. As noted earlier, present measurements were limited to conditions where $\delta_{\mathrm{D}} / \mathrm{r} r<1$ and radiative heat losses were small, in order to avoid complications due to flame unsteadiness, curvature and radiative transport; therefore, behavior near flammability limits and quenching conditions could not be assessed.

\section{Experimental Methods}

The present experiments were carried out in the spherical windowed chamber used for recent studies of laminar-premixed-flame/stretch interactions. ${ }^{4-9}$ The combustible mixture was prepared in the chamber and then spark-ignited at the center of the chamber using minimum spark ignition energies to control ignition disturbances. The flames were observed using high speed (up to $\mathbf{4 0 0 0}$ pictures per second) motion picture shadowgraphy. Once combustion was completed, the chamber was vented and then flushed with air until it cooled to the allowable initial temperature range of the experiments (generally $298 \pm(3-5) \mathrm{K}$ ).

The test chamber was evacuated to begin preparing a mixture for a test. The appropriate volume of liquid fuel was then injected into the chamber using a gastight syringe. After fuel injection, the chamber was allowed to stand for 5-10 minutes to insure complete evaporation of the fuel. The chamber was then filled with air (or the desired $\mathrm{O} / \mathrm{N}$ mixture) to the desired final pressure and mixed for 10 minutes using a small metal fan located within the chamber. After operation of the fan was ended, the motion of the gas within the chamber was allowed to decay for another ten minutes before the mixture was ignited. Using these procedures, the flame propagation process was spherically symmetric with no evidence of significant flow disturbances in the unburned gas.

The present measurements were limited to flames having diameters greater than $10 \mathrm{~mm}$ to avoid ignition disturbances. Measurements were also limited to flames having diameters less than $60 \mathrm{~mm}$, which implies pressure increases within the gas mixture less than $0.4 \%$ of the initial gas pressure during the period where flame propagation ratios were measured. Naturally, no test results are reported in the following where the flame surface was distorted or wrinkled due to effects of buoyancy or flame instability. Measurements were limited to $\delta_{\mathcal{D}} / r_{\mathrm{f}} \leq 2 \%$, similar to Refs. $4-9$, so that 
effects of curvature and transient phenomena associated with large flame thicknesses were small. Finally, estimates showed that radiative heat losses were less than $5 \%$ of the rate of chemical energy release within the flames, implying small effects of radiation on flame properties. For these conditions, the laminar burning velocity and flame stretch are given by the following expressions $^{: 12}$

$$
S_{L}=\left(\rho_{b} / \rho_{u}\right) d r_{d} / d t, \quad K=\left(2 / r_{f}\right) d r_{P} / d t
$$

The density ratio needed in Eq. (3) was computed assuming adiabatic constant-pressure combustion with the same fuel-equivalence ratio (or concentrations of elements) in the unburned and bumed gases. The computations to find the density ratios were completed using the algorithms of McBride et al. ${ }^{13}$ and Reynolds ${ }^{14}$ with both yielding the same results. This approach agrees with past determinations of the properties of stretched laminar flames, see Refs. 4-9 and references cited therein, however, use of the unstretched density ratio in this way is a convention that ignores preferential diffusion effects that modify local mixture fractions and thermal energy transport and cause local changes of the density ratios of stretched flames. The convention is convenient, however, because a single density ratio relates all flame speeds and laminar burning velocities, present methods are unchanged from earlier work which facilitates comparisons of measurements, and the approach retrieves the correct flame displacement velocity, $\mathrm{dr}_{\mathrm{f}} \mathrm{d} \mathrm{d}$, for a particular flame condition and $\mathrm{Ka}$. Given reliable structure predictions for various levels of stretch, however, density ratios should be computed as a function of stretch so that the actual laminar burning velocities and mass burning rates of these flames can be estimated.

Final results were obtained by averaging the measurements of 4-6 tests at each condition. Experimental uncertainties were estimated as described in Ref. 4 and references cited therein; the present uncertainties (95\% confidence) are as follows: $S_{L}$ less than $10 \%$, Ka less than $20 \%$ and $|\mathrm{Ma}|$ less than $25 \%$ for $|\mathrm{Ma}|>1$ and less than $25 /|\mathrm{Ma}| \%$ for $|\mathrm{Ma}|<1$.

Present test conditions and major results are summarized in Table 3 for combustion in air at atmospheric pressure, in Table 4 for combustion in various oxygen/nitrogen mixtures at atmospheric pressure, and in Table 5 for combustion in air at various pressures. The total test range includes nhexane, n-heptane, iso-octane, methyl-alcohol and ethyl-alcohol as fuels, concentrations of oxygen in the nonfuel portion of the mixture of $19-33 \%$ (by volume), pressures of 0.5-2.0 atm., fuel-equivalence ratios of $0.80-1.60$ and reactant gas temperatures of $298 \pm 5 \mathrm{~K}$.

\section{Results and Discussion}

\section{Elame Stability and Evolution}

Three kinds of flame surface instabilities were observed during the present investigation: preferential diffusion instability, hydrodynamic instability and buoyant instability. Preferential diffusion instability (stability) was associated with negative (positive) Markstein numbers because bulges of the flame surface that are concave (convex) toward the combustion products have positive (negative) Karlovitz numbers (similar to Eq. (3) for spherical flames) and thus increased (decreased) laminar burning velocities through Eq. (1); as a result, the bulges grow (decay) and the flame is unstable (stable) to preferential diffusion effects. Hydrodynamic and buoyant instabilities were also observed; they are associated with effects of accelerating a light combustion product gas toward a heavy reactant gas as the flame propagates and effects of gravity introducing buoyant motion of the light combustion product gas in its heavy gas surroundings.

Shadowgraph photographs of flame surfaces after distortion by the three types of instabilities for outwardly-propagating spherical flames appear in Kwon et al., ${ }^{4}$ Aung et al. ${ }^{7}$ and references cited therein. The presence of preferential diffusion instability could be identified by the development of irregular (chaotic) distortions of the flame surface relatively early in the flame propagation process. In contrast, hydrodynamic instability could be identified by the development of a somewhat regular cellular disturbance pattem on the flame surface rather late in the flame propagation process, similar to the observations of $\mathrm{Groff}^{37}$ for propane/air flames. Finally, the appearance of buoyant instability was readily detected by distortion of the flame as a whole from a spherical shape as well as a tendency for the centroid of the flame image to move upward. Measurements were ended when flame surface distortions due these instabilities were observed. Typical of past work, ${ }^{4-9}$ however, the onset of preferential diffusion instability was sufficiently delayed so that laminar burning velocities could be measured for a time in any event. Similarly, the onset of hydrodynamic and buoyant instabilities generally were observed a radii larger than the range of the measurements for present test conditions.

\section{Euel-Vapor/Air Flames at STP}


Buming Velocity/Stretch Interactions. Similar to past observations, ${ }^{4-9}$ values of $S_{L}$ yielded linear plots when plotted as a function of $\mathrm{Ka}$ according to Eq. (I). This implies that the values of the $\mathrm{Ma}$ were independent of $\mathrm{Ka}$ over the present test range and provided a straightforward interpolation to $\mathrm{Ka}=0$ to find $S_{L .}$. This procedure was used to find the values of $S_{L}$ and Ma summarized in Tables 3-5. Then given $S_{L}$, plots of $S_{L} / S_{L}$ as a function of Ka were constructed as suggested by Eq. (1). The resulting plots for fuelvapor/air flames at STP are plotted in Figs. 1-5 for flames fueled with n-hexane, n-heptane, iso-octane, methyl-alcohol and ethyl-alcohol, respectively. On these plots, open symbols are used to denote neutral and stable preferential-diffusion conditions ( $\mathrm{Ma} \geq 0$ ) while darkened symbols are used to denote unstable preferential-diffusion conditions $(\mathrm{Ma}<0)$. The ranges of the measurements for strongly unstable conditions (large negative slopes or large negative Markstein numbers) are more abbreviated than the rest due to the relatively early transition to chaotically wrinkled flame surfaces as a result of preferential-diffusion instability.

The results illustrated in Figs. 1-5 are qualitatively similar to past findings for a variety of reactant mixtures. ${ }^{49}$ The plots are linear, implying values of $\mathrm{Ma}$ independent of $\mathrm{Ka}$ for each flame condition. Present results involve rather modest values of flame stretch $\mathrm{Ka}$ $<0.2$ ), however, and are not close to extinction conditions where Ka would be on the order of unity and flame response to stretch is likely to change. Even for the present modest ranges of $\mathrm{Ka}$, however, preferential diffusion/stretch interactions are substantial with values of $S_{L} / S_{L-}$ varying in the range 0.4-4.0. This implies substantial potential for flame-surface/turbulence interactions within turbulent premixed flames of these reactants, with turbulent distortion of flame surfaces being enhanced and retarded for unstable and stable preferential diffusion conditions, respectively. ${ }^{4}$

The results illustrated in Figs. 1-5 indicate that flame response to stretch is significantly greater for the paraffin vapors than for the alcohol vapors, while all the vapors tend to be stable (unstable) for fuel-lean (rich) conditions, respectively. These trends are in qualitative agreement with classical ideas about preferential diffusion/stretch interactions and stability in laminar

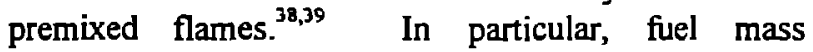
diffusivities progressively decrease with increasing molecular weight tending to increase the potential for preferential diffusion effects for the paraffins compared to the much lighter alcohols. Furthermore, fuel mass diffusivities generally are smaller than the rest of the species in the flame which implies a tendency for the mixture to become leaner with increasing stretch; this tends to decrease (increase) laminar burning velocities for fuel-lean (-rich) conditions, correspondingly leading to stable (unstable) preferential diffusion behavior. Other effects of flame temperatures and pressures on preferential diffusion/stretch interactions, however, appear to involve more complex behavior, as discussed later.

Unstretched_Laminar Buming Velocities. Values of measured and predicted laminar buming velocities are plotted in Figs. 6-10 for flames fueled with n-hexane, nheptane, iso-octane, methyl-alcohol and ethyl-alcohol, respectively. On these plots, measured values of laminar burning velocities are indicated by symbols with darkened symbols indicating stretch-corrected results to find $S_{\mathrm{L}}$. Predictions are shown as lines and all calculations were carried out for unstretched flames. Flame conditions for the various measurements and predictions are summarized in Tables 1 and 2, respectively. Among the measurements, the results of Bradley et al. ${ }^{10}$ were actually obtained at $358 \mathrm{~K}$, while the results of Egolfopoulos et al. ${ }^{27,20}$ have been extrapolated to $298 \mathrm{~K}$ from measurements at temperatures of $318-453 \mathrm{~K}$; all other measurements illustrated in Figs. 6-10 are for an unburned gas temperature of $298 \mathrm{~K}$.

The stretch-corrected measurements of laminar burning velocities of Bradley et al. ${ }^{10}$ for iso-octane (Fig. 8) are generally larger than the other stretch-corrected results for this fuel due to Davis and $\mathrm{Law}^{29}$ and the present investigation. This behavior is expected, however, due to the larger unburned gas temperature for the results of Bradley et al. ${ }^{10}$ than the rest, e.g., $358 \mathrm{~K}$ compared to $298 \mathrm{~K}$. The agreement between the remaining stretch-corrected laminar burming velocities of Davis and $\mathrm{Law}^{2 \mathrm{~g}}$ and the present investigation for the various fuel vapors, however, generally is poorer than past observations of stretch-corrected laminar burning velocities for gaseous fuels. There are two major reasons for this behavior: problems of vaporizing and mixing liquid fuels tend to increase experimental uncertainties, and extrapolation of the measurements of Egolfopoulos et al. ${ }^{27,28}$ also increases experimental uncertainties. Comparisons between the stretch-corrected and uncorrected laminar burning velocities are hard to quantify because experimental uncertainties generally are not stated for the uncorrected measurements. The most consistent trend, however, is that the uncorrected laminar burning velocities tend to be larger than the stretch-corrected results for both fuel-lean and fuel-rich conditions. 
In view of the rather strong sensitivity of the present flames to stretch, however, differences between the stretch-corrected and uncorrected laminar burning velocities are surprisingly modest. In general, differences among the various predictions and the various predictions and measurements are comparable, suggesting less difficulties in predicting unstretched laminar burning velocities than other flame properties.

Markstein Numbers. Measurements and predictions of Markstein numbers for the fuel-vapor/air flames at atmospheric pressure are plotted in Fig. 11. Measurements shown in the figure include results from Bradley et al. ${ }^{10}$ for iso-octane/air mixtures at an initial temperature of $358 \mathrm{~K}$ and the present measurements for all the fuel vapors at an initial temperature of $298 \mathrm{~K}$. Predictions of Muller et al. ${ }^{35}$ for iso-octane/air mixtures at an initial temperature of $298 \mathrm{~K}$ are shown on the plot; these predictions were obtained from a simplified analysis as opposed to the detailed mechanism summarized in Table 2. The agreement between the measurements of Bradley et al. $^{10}$ and the present investigation is very good in spite of the different initial temperatures; results considered later will show that the somewhat reduced values of Markstein numbers at the larger initial mixture temperature are quite reasonable. The predictions of Markstein numbers due to Müller et al. $^{35}$ are only qualitatively correct, which is typical of the performance of their simplified approach for other heavy hydrocarbons. ${ }^{33,40}$

The plots of Fig. 11 highlight the strong sensitivity of the paraffin-fueled flames to preferential diffusion/stretch interactions due to the rather large absolute values of these Markstein numbers, in the range 30 to -20 after including the results of Bradley et al. ${ }^{10}$ The corresponding sensitivity of the alcohol-fueled flames to preferential diffusion/stretch interactions is seen to be much weaker, with Markstein numbers only in the range 0 to -5 . The neutral preferential diffusion condition $(\mathrm{Ma}=0)$ is observed for fuel-equivalence ratios of roughly 1.1-1.2 for all the fuel vapors, which corresponds to the maximum laminar burning velocity conditions seen in Figs. 6-10. Finally, positive and negative Markstein numbers, associated with stable and unstable preferential diffusion behavior, are generally observed for fuel-lean and fuel-rich conditions, respectively. As noted earlier, all these trends are consistent with classical ideas about preferential diffusion/stretch interactions based on simple consideration of the preferential diffusion of the fuel compared to other major gas species.

\section{$\mathrm{n}-\mathrm{Hexane} / \mathrm{O}_{2} / \mathrm{N}_{2}$ Elames at ST}

Potential Behavior of Practical Flames, Most practical premixed fuel-vapor/air flames operate with considerably larger flame temperatures and pressures than the test conditions considered thus far, therefore, whether the strong preferential diffusion/stretch interactions of the present flames with reactants at STP conditions persist to practical flame conditions is an issue. Effects of temperature on flame sensitivity to preferential diffusion/stretch interactions are not well known but past studies for a variety of fuels suggest increased tendencies toward unstable flame behavior due to preferential diffusion effects with increasing pressure, see Hassan et al. ${ }^{8,9}$ and references cited therein. Thus, to gain more insight about this issue, effects of flame temperature and pressure on the sensitivity of hydrocarbon flames to preferential diffusion/stretch interactions was studied experimentally considering nhexane $/ \mathrm{O}_{2} / \mathrm{N}_{2}$ reactant mixtures. This information was obtained by varying flame temperatures through changes of $\mathrm{O}_{2}$ concentrations in the nonfuel gases at STP, and by varying flame pressures for fuel/air mixtures at ST. These results will be considered next.

Effect of Temperature on Flame Response to Stretch. Experiments undertaken to find the effect of flame temperature on flame response to stretch are summarized in Table 4. These results are illustrated in Figs. 12 and 13 for fuel-lean $(\phi=0.8)$ and stoichiometric conditions, respectively. These figures consist of plots of unstretched laminar burning velocities and Markstein numbers as a function of oxygen concentration in the nonfuel gases.

Increasing the flame temperature by increasing the oxygen concentration yields a corresponding increase of $S_{L}$ for the results illustrated in Figs. 12 and 13. This behavior follows because increased flame temperatures at a fixed pressure tend to increase radical concentrations in the reaction zone of the flame. Then, based on the well known proportionality between radical concentrations in the reaction zone and laminar burning velocities, ${ }^{41}$ laminar burning velocities increase accordingly.

The corresponding variation of Markstein numbers with increasing flame temperatures seen in Figs. 12 and 13 is quite interesting. For both fuel-equivalence ratios, the Markstein numbers initially decrease with increasing flame temperature, and then asymptotically approach $\mathrm{Ma}=0$. This behavior is particularly evident for stoichiometric conditions in Fig. 13, where initial values of the Markstein numbers are relatively small so that the range of oxygen concentrations where $\mathrm{Ma} \approx 0$ is 
relatively broad. This behavior suggests that increased radical concentrations at increased flame temperatures tends to reduce the sensitivity of the present flames to effects of stretch. Naturally, this behavior is not explained by classical preferential diffusion concepts as described in Refs. 38 and 39.

Effect of Pressure on Flame Response to Stretch. Experiments undertaken to find the effect of flame pressure on flame response to stretch are summarized in Table 5. These results are illustrated in Fig. 14 for combustion in air at stoichiometric conditions. The figure consists of plots of unstretched laminar burning velocities and Markstein numbers as a function of pressure.

Increasing the flame pressure yields a progressive reduction of $S_{L_{L}}$ for the results illustrated in Fig. 14. This behavior follows due to increased rates of threebody recombination reactions with increasing pressure which tends to reduce radical concentrations in the reaction zone of the flame. Then, the corresponding proportionality between radical concentrations in the reaction zone and laminar burning velocities, ${ }^{4 !}$ discussed earlier, implies reduced laminar burning velocities with increasing pressure.

The associated variation of Markstein numbers with increasing pressure is generally similar to past observations for a variety of premixed flames, see Refs. 8 and 9 and references cited therein. In particular, Markstein numbers progressively decrease and become negative over wide ranges of fuel-equivalence ratios, which enhances flame sensitivity to preferentialdiffusion/stretch instability. This increased sensitivity for unstable behavior due to preferential-diffusion/stretch interactions appears to be caused by reduced radical concentrations in the reaction zone but the mechanism of this behavior is not known and also is not explained by classical preferential-diffusion/stability concepts. In addition, whether the opposing effects of increased temperatures and increased pressures enhances or retards the sensitivity of practical flames to preferentialdiffusion/stretch interactions compared to laboratory experiments for conditions near STP, remains an open issue that clearly should be resolved.

\section{Conclusions}

Effects of positive flame stretch on laminar buming velocities were studied experimentally for hydrocarbonvapor/O/N flames. The measurements were made for outwardly-propagating spherical flames using methods developed earlier. ${ }^{49}$ Present measurements were compared with the earlier measurements and detailed numerical simulations in the literature summarized in Tables 1 and 2, respectively. The present test conditions and findings are summarized in Tables 3-5. The major conclusions of the study are as follows:

1. Preferential-diffusion/stretch interactions were conveniently correlated using the local conditions hypothesis similar to past work, ${ }^{49}$ because this yielded Markstein numbers that were relatively independent of Karlovitz numbers. Present observations were limited to Karlovitz numbers less than 0.2, however, and greater variations of Markstein numbers can be anticipated as quenching conditions are approached for Karlovitz numbers near unity.

2. Preferential-diffusion/stretch interactions were substantial for heavy liquid hydrocarbon vapors, yielding ratios of unstretched to stretched laminar burning velocities in the range $0.4-4.0$, even for the present modest levels of stretch (Karlovitz numbers).

3. Various stretch-corrected measurements and predictions of unstretched laminar burning velocities exhibited poorer agreement for hydrocarbon-vapor flames than earlier results for gaseous hydrocarbon flames. This behavior is caused by increased experimental uncertainties due to problems of vaporizing and mixing liquid fuels and effects of extrapolating measurements at elevated temperatures to standard temperature conditions, as well as increased computational uncertainties due to less well developed chemical mechanisms for heavy hydrocarbon fuels.

4. Increasing flame temperatures tended to reduce flame sensitivity to stretch while increasing pressures increased tendencies toward preferential-diffusion instability behavior. Thus, whether the strong preferential-diffusion/stretch interactions observed for heavy hydrocarbon flames at STP persist at the larger pressures and temperatures of most practical applications is an open issue that clearly merits attention in the future.

5. Preferential-diffusion instabilities were properly observed when Markstein numbers were negative and lead to the growth of irregular (chaotic) flame surface disturbances early in the flame propagation process; nevertheless, more regular (cellular) disturbances of flame surfaces, typical of hydrodynamic instabilities, were still observed at large flame radii when Markstein numbers were positive.

\section{Acknowledgments}

This research was supported in part by NSF Grants CTS-9019813 and 9321959 under the Technical Management of M.J. Linevsky and F. Fisher. Support 
from the Rackham Fellowship Program of the University of Michigan for O.C. Kwon and the Peace Fellowship Program of Egypt for M.I. Hassan is also gratefully acknowledged.

\section{$\underline{\text { References }}$}

'Dowdy, D.R., Smith, D.B., Taylor, S.C., and Williams, A., "The Use of Expanding Spherical Flames to Determine Burning Velocities and Stretch Effects on Hydrogen/Air Mixtures," Twenty-Third Symposium (International) on Combustion, The Combustion Institute, Pittsburgh, 1990, pp. 325-333.

'Brown, M.J., McLean, I.C., Smith, D.B., and Taylor, S.C., "Markstein Lengths of $\mathrm{CO} / \mathrm{H}_{2} / \mathrm{Air}$ Flames, Using Expanding Spherical Flames," TwentySixth Symposium (Intemational) on Combustion, The Combustion Institute, Pittsburgh, 1996, pp. 875-882.

${ }^{3}$ Karpov, V.P., Lipatnikov, A.N., and Wolanski, P., "Finding the Markstein Number Using the Measurements of Expanding Spherical Laminar Flames," Combust. Flame, Vol. 109, No. 3, 1996, pp. 436-448.

${ }^{4} K w o n$, S., Tseng, L.-K., and Faeth, G.M., 'Laminar Buming Velocities and Transition to Unstable Flames in $\mathrm{H}_{2} / \mathrm{O}_{2} / \mathrm{N}_{2}$ and $\mathrm{C}_{3} \mathrm{H}_{8} / \mathrm{O}_{2} / \mathrm{N}_{2}$ Mixtures," Combust. Flame, Vol. 90, No. 3, 1992, pp.230-246.

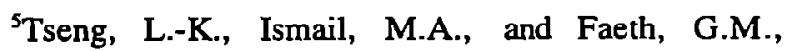
"Laminar Burning Velocities and Markstein Numbers of Hydrocarbon/Air Flames," Combust. Flame, Vol. 95, No. 4, 1993, pp. 410-426.

${ }^{6}$ Aung, K.T., Tseng, L.-K., Ismail, M.A., and Faeth, G.M., "Response to Comment by S.C. Taylor and D.B. Smith on "Laminar Burning Velocities and Markstein Numbers of Hydrocarbon/Air Flames," Combust. Flame, Vol. 102, No. 4, 1995, pp. 526-530.

${ }^{7}$ Aung, K.T., Hassan, M.I., and Faeth. G.M., "Flame/Stretch Interactions of Laminar Premixed Hydrogen/Air Flames at Normal Temperature and Pressure," Combust. Flame, Vol. 109, No. 1/2, 1997, pp. 1-24.
${ }^{8}$ Hassan, M.I., Aung, K.T., and Faeth, G.M., "Measured and Predicted Properties of Laminar Premixed Methane/Air Flames at Various Pressures," Combust. Flame, Vol. 115, No. 4, 1998, pp. 539-550.

${ }^{9}$ Hassan, M.I., Aung, K.T., Kwon, O.C., and Faeth, G.M., "Properties of Laminar Premixed Hydrocarbon/Air Flames at Various Pressures," I. Prop. Power, Vol. 14, No. 4, 1998, pp. 479-488.

${ }^{10}$ Bradley, D., Hicks, R.A., Lawes, M., Sheppard, C.G.W., and Woolley, R., "The Measurement of Laminar Burning Velocities and Markstein Numbers for Iso-Octane-Air and Iso-Octane-n-Heptane in Air Mixtures at Elevated Temperatures and Pressures in an Explosion Bomb," Combust. Elame, Vol. 115, No. 1/2, 1998, pp. 126-144,

"Markstein, G.H., Non-Steady Flame Propagation, Pergamon, New York, 1964, p. 22.

${ }^{12}$ Strehlow, R.A., and Savage, L.D., "The Concept of Flame Stretch," Combust. Flame, Vol. 31, No. 2, 1978, pp. 209-211.

${ }^{13}$ McBride, B.J., Reno, M.A., and Gordon, S., "CET93 and CETPC: An Interim Updated Version of the NASA Lewis Computer Program for Calculating Complex Chemical Equilibrium with Applications," NASA Technical Memorandum 4557, 1994.

${ }^{14}$ Reynolds, W.C., "The Element Potential Method for Chemical Equilibrium Analysis: Implementation in the Interactive Program STANJAN," Department of Mechanical Engineering Report, Stanford University, Stanford CA, 1986.

${ }^{15}$ Sachsse, Von H., and Bartholome, E., "Beiträge zen Frage der Flammengeschwindigkeit," Z. Elektrochem., Vol. 53, No. 4, 1949, pp.183-190.

${ }^{16}$ Gerstein, M., Levine, O., and Wong, E.L., "The Determination of Fundamental Burnign Properties of Hydrocarbons by a Revised Tube Method," I. Amer. Chem. Soc., Vol. 73, No. 1, 1951, pp.418-422. 
${ }^{17}$ Dugger, G.L., and Graab, D.D., "Flame Velocities of Hydrocarbon-Oxygen-Nitrogen Mixtures," Fourth Symposium (Intemational) on Combustion, The Combustion Institute, Pittsburgh, 1952, pp. 302-310.

${ }^{18}$ Wiser, W.H., and Hill, G.R., "A Kinetic Comparison of the Combustion of Methyl Alcohol and Methane," Fifth Symposium (International) on Combustion, The Combustion Institute, Pittsburgh, 1954, p. 553-558.

${ }^{19}$ Franze, Van C. and Wagner, H. Gg., "Ausbreitung Laminarer Flammen in Vorgemischten Gasen: Messungen und Theorie der Flammengeschwindigheit," Z. Electrochem, Vol. 60, No. 6, 1956, pp. 525-556

${ }^{20} \mathrm{Heimel}, \mathrm{S}$. , and Weash, R.C., "Effect of Initial Mixture Temperature on the Burning Velocity of Benzene-Air, n-Heptane-Air, and Isooctane-Air Mixtures," Sixth Symposium (Intemational) on Combustion, The Combustion Institute, Pittsburgh, 1956, pp. 296-302.

${ }^{21}$ Golovina, E.S., and Fyodorov, G.G., "Influence of Physical and Chemical Factors on Buming Velocity," Sixth Symposium (Intemational) on Combustion, The Combustion Institute, Pittsburgh, 1956, pp. 88-96.

${ }^{22}$ Gibbs, G.J., and Calcote, H.F., "Effect of Molecular Structure on Burning Velocity," I. Chem. Engr. Data, Vol. 4, 1959, pp. 226-237.

${ }^{23}$ Gülder, O.L., "Laminar Burning Velocities of Methanol, Ethanol and Iso-octane-Air Mixtures," Nineteenth Symposium (International) on Combustion, The Combustion Institute, Pittsburgh, 1982, pp. 275281.

${ }^{24}$ Metghalchi, M., and Keck, J.C., "Burning Velocity of Mixtures of Air with Methanol, Isooctane, and Indolene at High Pressure and Temperature," Combust. Flame, Vol 48, No. 2, 1982, pp. 191-210.

${ }^{25}$ James, E.H., "Laminar Buming Velocities of IsoOctane-Air Mixtures - A Literature Review," SAE Paper No. 870170, 1987.
${ }^{26}$ Bradley, D., Dixon-Lewis, G., Habik, S.E., Kwa, L.K., and El-Sherif, S., "Laminar Flame Stucture and Burning Velocities of Premixed Methanol-Air," Combust. Flame, Vol. 85, Nos. 1 and 2, 1991, pp. 105-120.

${ }^{27}$ Egolfopoulos, F.N., Du, D.X., and Law, C.K., “A Comprehensive Study of Methanol Kinetics in FreelyPropagating and Burner-Stabilized Flames, Flow and Static Reactors, and Shock Tubes," Combust. Sci. Tech., Vol. 83, Nos. 1-3, 1992, pp. 33-75.

${ }^{28}$ Egolfopoulos, F.N., Du, D.X., and Law, C.K., "A Study of Ethanol Oxidation Kinetics in Laminar Premixed Flames, Flow Reactors, and Shock Tubes," Twenty-Fourth Symposium (Intemational) on Combustion, The Combustion Institute, Pittsburgh, 1992, pp. 833-841.

${ }^{29}$ Davis, S.G., and Law, C.K., "Laminar Flame Speeds and Oxidation Kinetics of iso-Octane/Air and nHeptane/Air Flames," Twenty-Seventh Symposium (International) on Combustion, The Combustion Institute, Pittsburgh, in press.

${ }^{30}$ Wamatz, J., "Chemistry of High Temperature Combustion of Alkanes up to Octane," Twentieth Symposium (International) on Combustion, The Combustion Institute, Pittsburgh, 1984, pp. 845-856.

${ }^{31}$ Lindstedt, R.P., and Maurice, L.Q., "Detailed Kinetic Modeling of n-Heptane Combustion," Combust. Sci. Tech., Vol. 107, Nos. 4-6, 1995, pp. 317-353.

${ }^{32}$ Nehse, M., Wamatz, J., and Chevalier, G., "Kinetic Modeling of the Oxidation of Large Aliphatic Hydrocarbons," Twenty-Sixth Symposium (Intemational) on Combustion, The Combustion Institute, Pittsburgh, 1996, pp. 773-780.

${ }^{33}$ Pitsch, H., Peters, N., and Seshadri, K., "Numerical and Asymptotic Studies of the Structure of Premixed iso-Octane Flames," Twenty-Sixth Symposium (Intemational) on Combustion, The Combustion Institute, Pittsburgh, 1996, pp. 763-771. 
${ }^{34}$ Held, T.J., Marchese, A.J., and Dryer, F.L., "A Semi-Empirical Reaction Mechanism for n-Heptane Oxidation and Pyrolysis," Combust. Sci. Tech., Vol. 123, No. 1-5, 1997, pp. 107-146.

${ }^{35}$ Müller, U.C., Bolling, M., and Peters, N., "Appoximations for Burning Velocities and Markstein Numbers for Lean Hydrocarbon and Methanol Flames," Combust. Flame, Vol. 108, No. 3, 1997, pp. 349-356.

${ }^{36}$ Braun, W.G., Danner, R.P., and Daubert, T.E., Technical Data Book - Petroleum Refining, 3rd ed., American Petroleum Institute, Washington, D.C., Vol. 2, 1976, Chapt, 7.

${ }^{37}$ Groff, E.G., “ The Cellular Nature of Confined Spherical Propane-Air Flames," Combust. Flame, Vol. 48,1982 , pp. 51-62.

${ }^{38}$ Manton, J., von Elbe, G., and Lewis, B., "Nonisotropic Propagation of Combustion Waves in
Explosive Gas Mixtures and Development of Cellular Flames," L. Chem. Phys., Vol. 20, 1952 , pp. 153158.

${ }^{39}$ Law, C.K., "Dynamics of Stretched Flames," Twenty-Second Symposium (International) on Combustion, The Combustion Institute, Pittsburgh, 1988, pp. 1381-1402.

${ }^{40}$ Kwon, O.-C., Aung, K.T., Tseng, L.-K., Ismail, M.A., and Faeth, G.M., "Comment on 'Approximations for Bum ing Velocities and Markstein Numbers for Lean Hydrocarbon and Methanol Flames' by U.C. Müller, B. Bollig and N. Peters," Combust. Elame, Vol. 116, 1999, pp. 310-312.

4lPadley, P.J., and Sugden, T.M., "Chemiluminescence and Radical Recombination in Hydrogen Flames," Seventh Symposium (Intemational) on Combustion, The Combustion Institute, Pittsburgh, PA, 1958, p. 235-244.

Table 1 Summary of Earlier Laminar Buming Velocity Measurements for Premixed Liquid-FuelVapor/O/N Flames

\begin{tabular}{|c|c|c|c|c|c|}
\hline Source" & Melhod & $\begin{array}{l}\text { Pressure } \\
\text { (atm) }\end{array}$ & $\begin{array}{l}\text { Equiv. } \\
\text { Ratio }\end{array}$ & $\begin{array}{l}\mathrm{O}_{2} \text { conc. } \\
\text { (\% vol. })^{\mathrm{b}}\end{array}$ & $\begin{array}{r}\text { Temp. } \\
\text { (K) }\end{array}$ \\
\hline \multicolumn{4}{|l|}{ n-HexandAir } & \multicolumn{2}{|c|}{ - } \\
\hline $\begin{array}{l}\text { Gerstein et al. }{ }^{16} \\
\text { Golovina and Fyodorov }{ }^{21}\end{array}$ & $\begin{array}{l}\text { Horizontal tube } \\
\text { Bunsen burner }\end{array}$ & $\begin{array}{l}1.0 \\
1.0\end{array}$ & $\begin{array}{l}1.01-1.29 \\
0.17-2.85\end{array}$ & $\begin{array}{r}21 \\
16-100\end{array}$ & $\begin{array}{l}298 \\
298\end{array}$ \\
\hline $\begin{array}{l}\text { n-Hepone/Air } \\
\text { Gerstein et al. } \\
\text { Heimel and Weast } \\
\text { Gibbs and Calcote } \\
\text { Davis and Law }\end{array}$ & $\begin{array}{l}\text { Horizontal ube } \\
\text { Bunsen burner } \\
\text { Bunsen burner } \\
\text { Twin flame }\end{array}$ & $\begin{array}{l}1.0 \\
1.0 \\
1.0 \\
1.0\end{array}$ & $\begin{array}{l}0.99-1.34 \\
0.86-1.28 \\
0.70-1.40 \\
0.70-1.70\end{array}$ & $\begin{array}{l}21 \\
21 \\
21 \\
21\end{array}$ & $\begin{array}{r}298 \\
308-579 \\
298 \& 373 \\
298\end{array}$ \\
\hline \multicolumn{6}{|l|}{ iso-Ocand/Air } \\
\hline $\begin{array}{l}\text { Sachsse and Bartholome } \\
\text { Dugger and Grab } \\
\text { Franze and Wagner19 } \\
\text { Heimel and Weast } \\
\text { Gibbs and Calcote } \\
\text { Gulder } \\
\text { Metghalchi and Keck } \\
\text { Bradley et al. }{ }^{10} \\
\text { Davis and Law }\end{array}$ & $\begin{array}{l}\text { 'Bunsen burner } \\
\text { Bunsen burner } \\
\text { Bunsen burner } \\
\text { Bunsen bumer } \\
\text { Bunsen burner } \\
\text { Spher.chamber } \\
\text { Spher.chamber } \\
\text { Spher.ehamber' } \\
\text { Twin llame' }\end{array}$ & $\begin{array}{r}1.0 \\
1.0 \\
1.0 \\
1.0 \\
1.0 \\
1.0-7.9 \\
0.4-50 \\
1.0-9.9 \\
1.0\end{array}$ & $\begin{array}{l}1.07 \\
1.00-1.05 \\
1.09 \\
0.85-1.18 \\
0.80-1.30 \\
0.75-1.35 \\
0.80-1.50 \\
0.80-1.30 \\
0.07-1.70\end{array}$ & $\begin{array}{r}21 \\
21-50 \\
21 \\
21 \\
21 \\
21 \\
16-21 \\
21 \\
21\end{array}$ & $\begin{array}{r}293 \\
311 \& 422 \\
293 \\
298-707 \\
298 \& 373 \\
300-500 \\
298-700 \\
358-450 \\
298\end{array}$ \\
\hline \multicolumn{6}{|l|}{ Methyl-Alcohol/Air } \\
\hline $\begin{array}{l}\text { Wiser and Hill" } \\
\text { Franze and Wagner" } \\
\text { Gibbs and Calcote } \\
\text { Gulder" } \\
\text { Metghalehi and Keek" } \\
\text { Egolfopoulos et al. }\end{array}$ & $\begin{array}{l}\text { Horizontal tube } \\
\text { Bunsen burner } \\
\text { Bunsen bumer } \\
\text { Spher.chamber } \\
\text { Spher.ehamber } \\
\text { Twin flame" }\end{array}$ & $\begin{array}{r}0.9 \\
1.0 \\
1.0 \\
1.0-7.9 \\
0.4-50 \\
1.0\end{array}$ & $\begin{array}{l}0.17-1.79 \\
1.09 \\
0.70-1.40 \\
0.70-1.40 \\
0.80-1.20 \\
0.50-1.97\end{array}$ & $\begin{array}{r}21-100 \\
21 \\
21 \\
21 \\
21 \\
21\end{array}$ & $\begin{array}{r}300 \\
293 \\
298 \& 373 \\
300-500 \\
298-700 \\
298-368^{\mathrm{r}}\end{array}$ \\
\hline Erhyl-Alcohol/Air & & & & - & \\
\hline $\begin{array}{l}\text { Gülder } 23 \\
\text { Egolfopoulos et al. }{ }^{21}\end{array}$ & $\begin{array}{l}\text { Spher,ehamber } \\
\text { Twin flame }\end{array}$ & $\begin{array}{r}1.0-7.9 \\
1.0\end{array}$ & $\begin{array}{l}0.70-1.40 \\
0.55-1.82\end{array}$ & $\frac{21}{21}$ & $\begin{array}{r}300-500 \\
298-453^{c}\end{array}$ \\
\hline
\end{tabular}


Table 2 Summary of Earlier Laminar Buming Velocity Predictions for Premixed Liquid Fuel-Vapor/Air Flames"

\begin{tabular}{|c|c|c|c|c|}
\hline \multirow{2}{*}{ Source } & \multirow{2}{*}{$\begin{array}{l}\text { Fuel Vapors } \\
\text { Considered }\end{array}$} & \multirow{2}{*}{$\begin{array}{l}\text { Temp. } \\
(\mathrm{K})\end{array}$} & \multicolumn{2}{|c|}{ Mechanism } \\
\hline & & & \# Species & Reac. \\
\hline Bradley et al. ${ }^{2 x}$ & methyl-alcohol & 300 & 17 & 40 \\
\hline Egolfopoulos et al. & methyl-alcohol & 298 & 30 & 171 \\
\hline Egolfopoulos et al. & ethyl-aleohol & 298 & 35 & 196 \\
\hline Davis and Law & $\begin{array}{l}\text { n-beptane, } \\
\text { iso-octane }\end{array}$ & 298 & 69 & 406 \\
\hline Warnate ${ }^{30}$ & $\begin{array}{l}\text { n-bexane, } \\
\text { n-beplane }\end{array}$ & 298 & 31 & 97 \\
\hline Lindstedt and Maurice," & n-heptane & 298 & 109 & 659 \\
\hline Nebse et al., 32 & n-heptane & 298 & $>66$ & $>197$ \\
\hline Pitsch et al..$^{33}$ & iso-octane & 328 & 109 & 967 \\
\hline Held et al., & n-beptane & 298 & 41 & 266 \\
\hline Muller et al. ${ }^{35}$ & $\begin{array}{l}\text { methyl-alcohol } \\
\text { n-beptane } \\
\text { iso-octane }\end{array}$ & $\begin{array}{l}298 \\
298 \\
298\end{array}$ & $\begin{array}{l}33 \\
51 \\
61\end{array}$ & $\begin{array}{l}116 \\
249 \\
257\end{array}$ \\
\hline
\end{tabular}

Flame conditions are for one alm and are summarized for results plorted here; see original source for complete range of tlame conditions considered. These predictions were for unstretched flames having negligible beat losses although Müller et al. ${ }^{35}$ find premixed-flame/streteh interactions using a simplified approach.

Table 3 Table of Test Conditions for Combustion in Air at Atmospherie Pressure"

\begin{tabular}{|c|c|c|c|c|c|c|c|}
\hline $\begin{array}{l}\phi \\
(-)\end{array}$ & $\begin{array}{l}p_{J} / p_{0} \\
(-)\end{array}$ & $\begin{array}{l}S_{L}^{\prime} \\
(\mathrm{mm} / \mathrm{s})\end{array}$ & $\begin{array}{l}S_{\mathrm{L}} \\
(\mathrm{mm} / \mathrm{s})\end{array}$ & $\begin{array}{c}\delta_{\mathrm{D}} \\
(\mu \mathrm{m})\end{array}$ & $\begin{array}{l}K_{\text {tran }} \\
\left(s^{-1}\right)\end{array}$ & $\begin{array}{c}\mathrm{K}_{2} \\
(-)\end{array}$ & $\begin{array}{r}\mathrm{Ma} \\
(-)\end{array}$ \\
\hline $\begin{array}{l}\text { n-Hes } \\
0.80 \\
0.90 \\
0.95 \\
1.00 \\
1.10 \\
1.20 \\
1.40 \\
1.60\end{array}$ & $\begin{array}{c}\text { cane/air: } 29 \\
7.21 \\
7.75 \\
7.97 \\
8.14 \\
8.29 \\
8.22 \\
7.99 \\
7.74\end{array}$ & 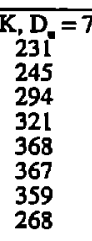 & $\begin{array}{c}\mathrm{mm}^{2} / \mathrm{s} \\
280 \\
294 \\
327 \\
353 \\
387 \\
367 \\
312 \\
167\end{array}$ & $\begin{array}{l}30 \\
30 \\
20 \\
20 \\
20 \\
20 \\
30 \\
50\end{array}$ & $\begin{array}{r}225 \\
302 \\
488 \\
496 \\
689 \\
736 \\
1,009 \\
649\end{array}$ & $\begin{array}{l}0.084 \\
0.078 \\
0.074 \\
0.058 \\
0.058 \\
0.044 \\
0.037 \\
0.034\end{array}$ & $\begin{array}{r}13.4 \\
10.5 \\
6.3 \\
5.9 \\
4.6 \\
0.0 \\
-8.7 \\
-16.8\end{array}$ \\
\hline $\begin{array}{l}n-H e \\
0.90 \\
1.00 \\
1.10 \\
1.20 \\
1.40 \\
1.60\end{array}$ & $\begin{array}{c}\text { plane/air. } 29 \\
7.77 \\
8.16 \\
8.30 \\
8.24 \\
8.02 \\
7.77\end{array}$ & $\begin{array}{l}K, D_{4}= \\
244 \\
275 \\
335 \\
378 \\
370 \\
307\end{array}$ & $\begin{array}{l}\mathrm{mm}^{2} / \mathrm{s}: \\
297 \\
315 \\
364 \\
382 \\
333 \\
230\end{array}$ & $\begin{array}{l}20 \\
20 \\
20 \\
20 \\
20 \\
30\end{array}$ & $\begin{array}{l}283 \\
394 \\
505 \\
813 \\
956 \\
705\end{array}$ & $\begin{array}{l}0.102 \\
0.067 \\
0.051 \\
0.044 \\
0.033 \\
0.029\end{array}$ & $\begin{array}{r}15.1 \\
10.2 \\
7.2 \\
1.1 \\
-7.5 \\
-15.1\end{array}$ \\
\hline $\begin{array}{l}\text { iso-0 } \\
0.90 \\
1.00 \\
1.10 \\
1.20 \\
1.40 \\
1.60\end{array}$ & $\begin{array}{c}\text { clane/air. } 29 \\
7.76 \\
8.16 \\
8.30 \\
8.23 \\
8.00 \\
7.74\end{array}$ & $\begin{array}{l}K_{2} D_{0}= \\
203 \\
262 \\
288 \\
317 \\
307 \\
288\end{array}$ & $\begin{array}{l}\mathrm{mm}^{2} / \mathrm{s}: \\
247 \\
312 \\
325 \\
336 \\
290 \\
195\end{array}$ & $\begin{array}{l}30 \\
20 \\
20 \\
20 \\
20 \\
30\end{array}$ & $\begin{array}{l}166 \\
344 \\
446 \\
476 \\
613 \\
514\end{array}$ & $\begin{array}{l}0.153 \\
0.083 \\
0.061 \\
0.037 \\
0.035 \\
0.028\end{array}$ & $\begin{array}{r}16.8 \\
12.8 \\
8.3 \\
3.9 \\
-5.5 \\
-16.5\end{array}$ \\
\hline $\begin{array}{l}\text { Mech } \\
0.80 \\
0.90 \\
1.00 \\
1.10 \\
1.20 \\
1.40\end{array}$ & $\begin{array}{c}\text { yl-alcohol/a } \\
7.17 \\
7.65 \\
8.00 \\
8.11 \\
8.04 \\
7.85\end{array}$ & $\begin{array}{l} \pm 3 \mathrm{~K} I \\
244 \\
305 \\
353 \\
410 \\
440 \\
433\end{array}$ & $\begin{array}{l}15.38 \mathrm{~m} \\
244 \\
305 \\
353 \\
402 \\
401 \\
361\end{array}$ & $\begin{array}{l}60 \\
50 \\
40 \\
40 \\
40 \\
40\end{array}$ & $\begin{array}{r}567 \\
831 \\
987 \\
1,209 \\
1,334 \\
1,298\end{array}$ & $\begin{array}{l}0.149 \\
0.132 \\
0.124 \\
0.098 \\
0.072 \\
0.068\end{array}$ & $\begin{array}{r}0.0 \\
0.0 \\
0.0 \\
-0.5 \\
-3.4 \\
-4.9\end{array}$ \\
\hline $\begin{array}{l}\text { Ethyl } \\
0.80 \\
0.90 \\
1.00 \\
1.10 \\
1.20 \\
1.40\end{array}$ & $\begin{array}{c}\text {-alcohol/air } \\
7.19 \\
7.71 \\
8.09 \\
8.21 \\
8.14 \\
7.92\end{array}$ & $\begin{array}{c} \pm 5 \mathrm{~K}, \mathrm{D} \\
249 \\
300 \\
331 \\
396 \\
399 \\
390\end{array}$ & $\begin{array}{c}1.95 \mathrm{~mm} \\
249 \\
300 \\
331 \\
382 \\
376 \\
343\end{array}$ & $\begin{array}{l}50 \\
40 \\
40 \\
30 \\
30 \\
30\end{array}$ & $\begin{array}{r}675 \\
817 \\
930 \\
1,247 \\
1,371 \\
1,426\end{array}$ & $\begin{array}{l}0.131 \\
0.107 \\
0.100 \\
0.084 \\
0.074 \\
0.065\end{array}$ & $\begin{array}{r}0.5 \\
0.2 \\
0.0 \\
-1.0 \\
-2.8 \\
-5.0\end{array}$ \\
\hline
\end{tabular}


Table 4 Summary of Test Conditions for $\mathrm{n}-\mathrm{Hexane} / \mathrm{O}_{1} \mathrm{~N}_{2}$ Fames

\begin{tabular}{|c|c|c|c|c|c|c|c|}
\hline $\begin{array}{c}O_{2}\left(\mathrm{O}_{2}+N_{2}\right) \\
(\%)\end{array}$ & $\begin{array}{l}P / p_{1} \\
(-)\end{array}$ & $\begin{array}{l}S_{L m}^{\prime} \\
(m+s)\end{array}$ & $\begin{array}{l}S_{L-} \\
(\mathrm{mm} / \mathrm{s})\end{array}$ & $\delta_{\infty}$ & $\frac{K_{\text {men }}}{\left(s^{-1}\right)}$ & $\begin{array}{l}\mathrm{Ka}_{\mathrm{mx}} \\
(-)\end{array}$ & $\begin{array}{l}\text { Ma } \\
(-)\end{array}$ \\
\hline \multicolumn{8}{|l|}{$=0.8:$} \\
\hline $\begin{array}{l}21 \\
23 \\
25 \\
27 \\
29 \\
31 \\
33\end{array}$ & $\begin{array}{l}7.21 \\
7.63 \\
8.02 \\
8.37 \\
8.68 \\
8.97 \\
9.23\end{array}$ & $\begin{array}{l}231 \\
284 \\
392 \\
482 \\
573 \\
611 \\
706\end{array}$ & $\begin{array}{l}280 \\
323 \\
422 \\
501 \\
583 \\
611 \\
706\end{array}$ & $\begin{array}{l}30 \\
20 \\
20 \\
20 \\
10 \\
10 \\
10\end{array}$ & $\begin{array}{r}225 \\
392 \\
599 \\
862 \\
1,120 \\
1,230 \\
1,468\end{array}$ & $\begin{array}{l}0.084 \\
0.067 \\
0.043 \\
0.037 \\
0.027 \\
0.026 \\
0.023\end{array}$ & $\begin{array}{r}13.4 \\
8.5 \\
6.1 \\
4.8 \\
2.5 \\
0.0 \\
0.0\end{array}$ \\
\hline \multicolumn{8}{|l|}{$\phi=1.0:$} \\
\hline $\begin{array}{l}19 \\
21 \\
23 \\
25 \\
27 \\
29 \\
31\end{array}$ & $\begin{array}{l}7.71 \\
8.14 \\
8.53 \\
8.89 \\
9.21 \\
9.51 \\
9.80\end{array}$ & $\begin{array}{l}240 \\
321 \\
412 \\
504 \\
583 \\
679 \\
764\end{array}$ & $\begin{array}{l}268 \\
353 \\
434 \\
504 \\
582 \\
680 \\
764\end{array}$ & $\begin{array}{l}30 \\
20 \\
20 \\
20 \\
10 \\
10 \\
10\end{array}$ & $\begin{array}{r}337 \\
496 \\
757 \\
992 \\
1,152 \\
1,329 \\
1,585\end{array}$ & $\begin{array}{l}0.072 \\
0.058 \\
0.043 \\
0.030 \\
0.025 \\
0.023 \\
0.021\end{array}$ & $\begin{array}{r}6.2 \\
5.9 \\
4.5 \\
0.0 \\
-0.1 \\
0.2 \\
0.0\end{array}$ \\
\hline
\end{tabular}

Reactants af $298 \pm 4 \mathrm{~K}$ and $1.0 \mathrm{~atm}, \bar{D}_{.}=7.78 \mathrm{~mm}^{2} / \mathrm{s}$.

Table 5 Summary of Test Conditions for n-Hexane/Air Flames at Various Pressures

\begin{tabular}{|c|c|c|c|c|c|c|c|}
\hline $\begin{array}{c}P \\
(\mathrm{am})\end{array}$ & $\begin{array}{c}P J / P_{b} \\
(-)\end{array}$ & $\begin{array}{l}S_{L}^{\prime} \\
(\mathrm{mm} / \mathrm{s})\end{array}$ & $\begin{array}{l}S_{L} \\
(\mathrm{~mm} / \mathrm{s})\end{array}$ & $\begin{array}{l}\delta_{D_{m}} \\
(\mu \mathrm{m})\end{array}$ & $\frac{K_{\operatorname{mix}}}{\left(s^{-1}\right)}$ & $\begin{array}{l}K_{\mathbf{a}_{\text {and }}} \\
-(-)\end{array}$ & $\begin{array}{l}M_{\mathbf{a}} \\
(-)\end{array}$ \\
\hline \multicolumn{8}{|c|}{$\phi=1.0:$} \\
\hline $\begin{array}{l}0.5 \\
1.0 \\
1.5 \\
2.0\end{array}$ & $\begin{array}{l}8.08 \\
8.14 \\
8.17 \\
8.20\end{array}$ & $\begin{array}{l}374 \\
321 \\
304 \\
291\end{array}$ & $\begin{array}{l}440 \\
353 \\
312 \\
291\end{array}$ & $\begin{array}{l}40 \\
20 \\
20 \\
10\end{array}$ & $\begin{array}{l}399 \\
496 \\
568 \\
547\end{array}$ & $\begin{array}{l}0.098 \\
0.058 \\
0.036 \\
0.026\end{array}$ & $\begin{array}{r}7.1 \\
5.9 \\
2.0 \\
-0.2\end{array}$ \\
\hline
\end{tabular}

Reactants at $298 \pm 3 \mathrm{~K}, \mathrm{D}_{\mathrm{u}}=7.78 / \mathrm{P}(\mathrm{atm}) \mathrm{mm}^{2} / \mathrm{s}$.

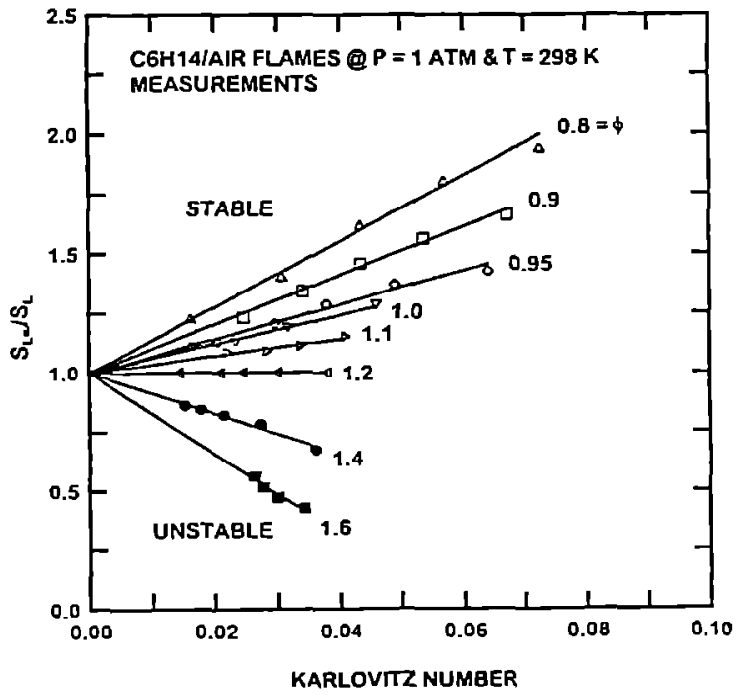

Fig. 1 Measured laminar burning velocities as a function of Karlovitz number and fuelequivalence ratio for $n$-hexane/air flames at STP.

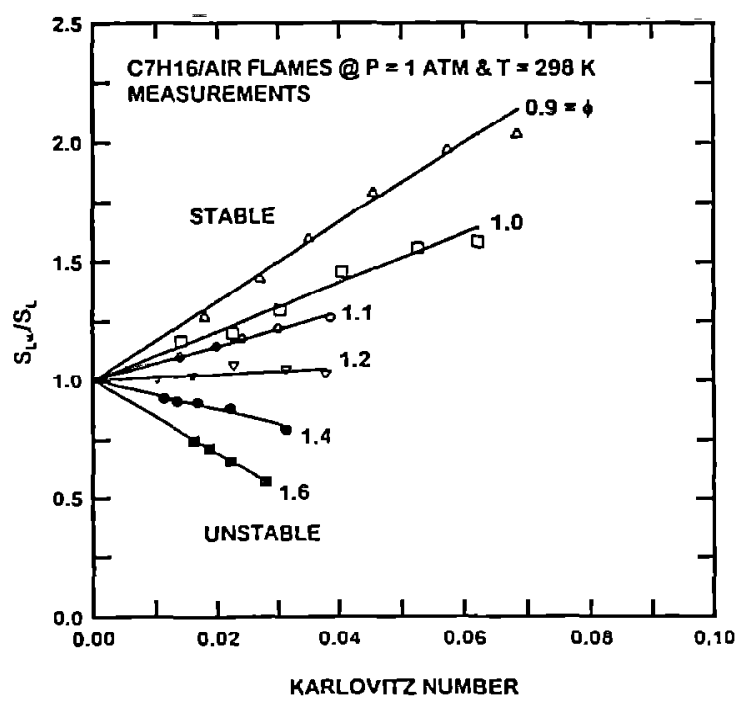

Fig. 2 Measured laminar buming velocities as a function of Karlovitz number and fuelequivalence ratio for $n$-heptane/air flames at STP. 


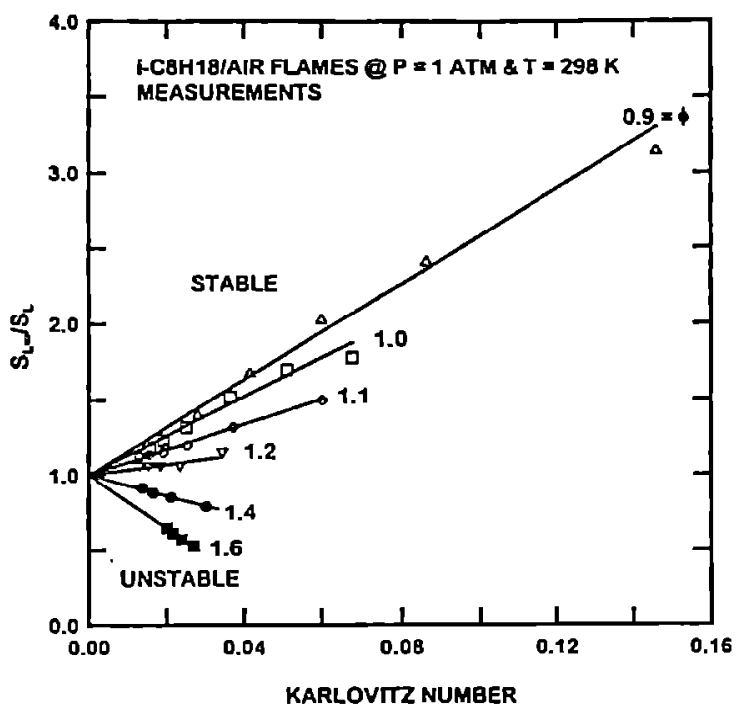

Fig. 3 Measured laminar burning velocities as a function of Karlovitz number and fuelequivalence ratio for iso-octane/air flames at STP.

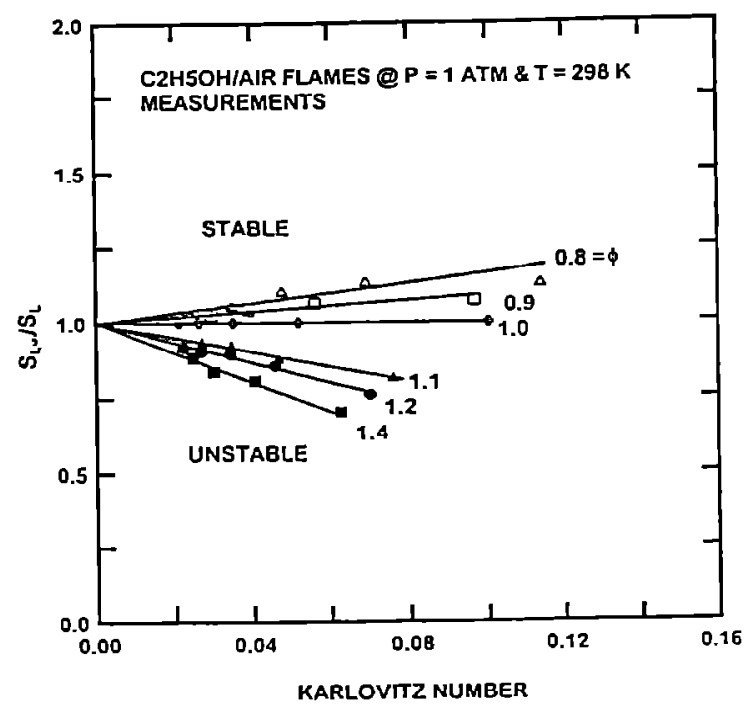

Fig. 5 Measured laminar burning velocities as a function of Karlovitz number and fuelequivalence ratio for ethyl-alcohol/air flames at STP.

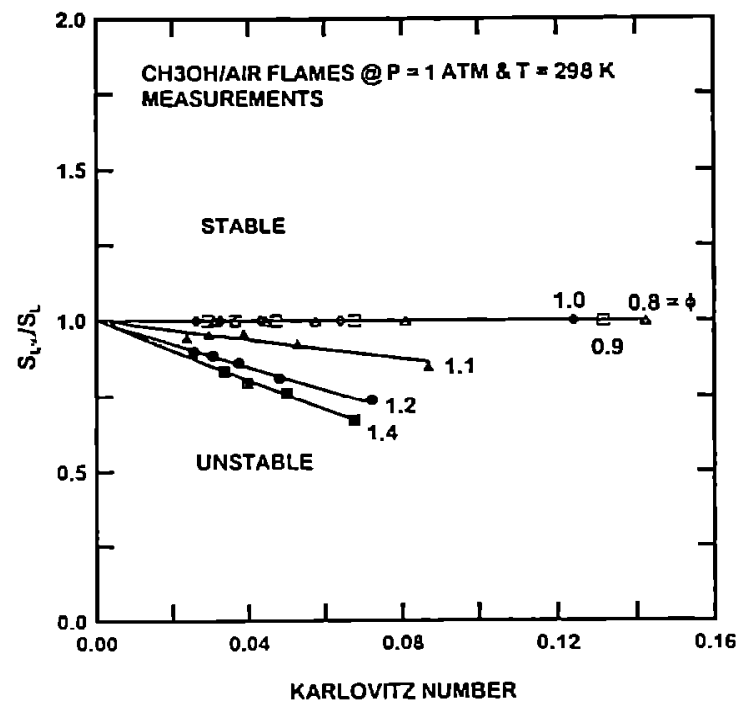

Fig. 4 Measured laminar burning velocities as a function of Karlovitz number and fuelequivalence ratio for methyl-alcohol/air flames at STP.

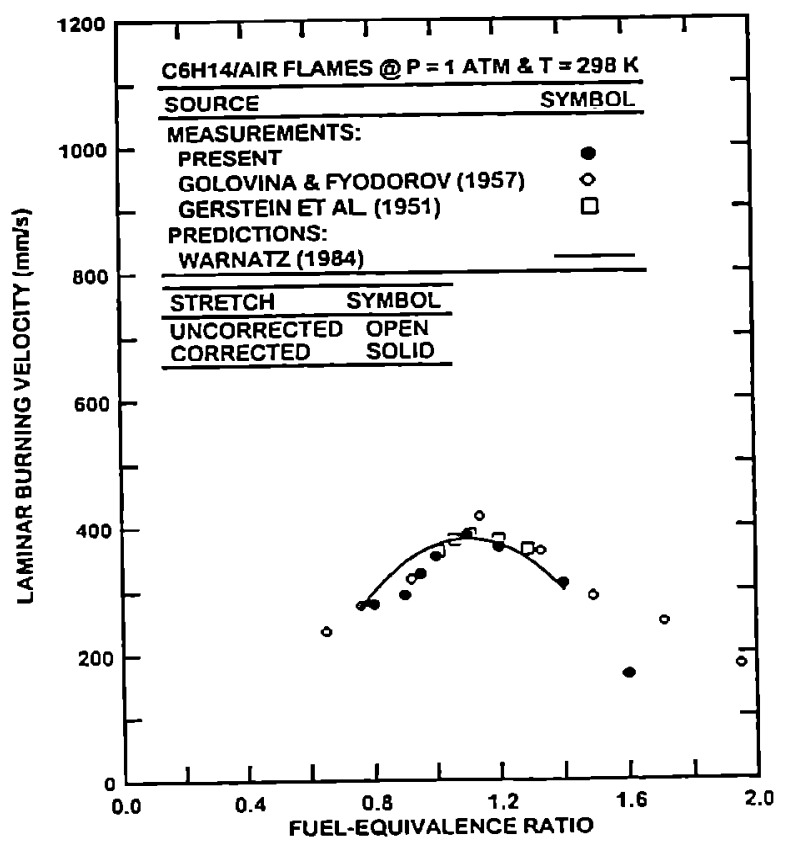

Fig. 6 Measured and predicted laminar burning velocities as a function of Karlovitz number and fuel-equivalence ratio for $\mathrm{n}$-hexane/air flames at STP. Measurements of Gerstein et al., ${ }^{16}$ Golovina and Fyodorov ${ }^{21}$ and the present investigation; predictions of Warnatz. ${ }^{30}$ 


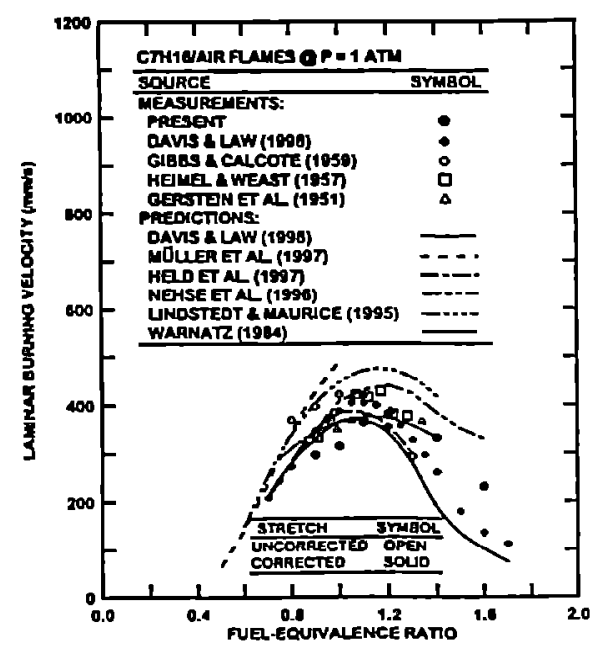

Fig. 7 Measured and predicted laminar burning velocities as a function of Karlovitz number and fuel-equivalence ratio for $\mathrm{n}$ heptane/air flames at STP. Measurcments of Gerstein et al., ${ }^{16}$ Heimel and Weast, ${ }^{20}$ Gibbs and Calcote, ${ }^{22}$ Davis and Law $^{29}$ and the present investigation; predictions of Davis and Law, ${ }^{29}$ Warnatz, ${ }^{30}$ Lindstedt and Maurice, ${ }^{31}$ Nehse et al.. ${ }^{32}$ Held et al., ${ }^{34}$ and Müller et al..$^{35}$

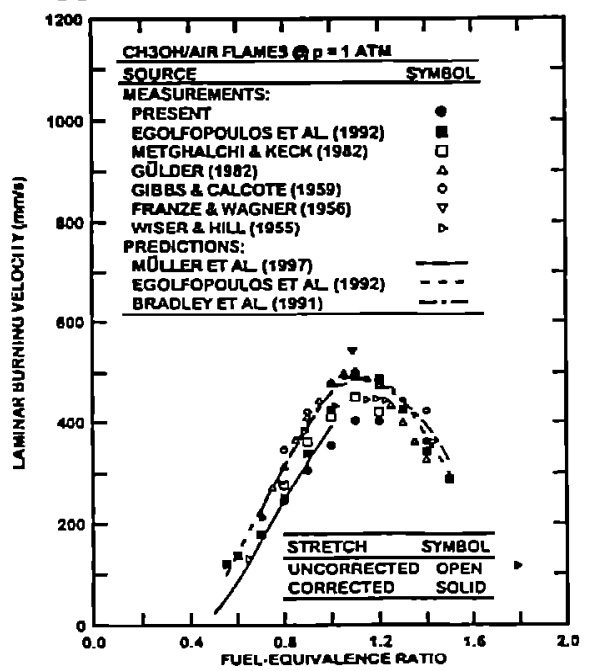

Fig. 9 Measured and predicted laminar burning velocities as a function of fuel-equivalence ratio and fuel-equivalence ratio for methylalcohol/air flames at STP. Measurements of Wiser and Hill, ${ }^{18}$ Franze and Wagner, ${ }^{19}$ Gibbs and Calcote, ${ }^{22}$ Gülder, ${ }^{23}$ Metghalchi and Keck, ${ }^{24}$ Egolfopoulos et al. ${ }^{27}$ and the present investigation; predictions of Bradley et al., ${ }^{10}$ Egolfopoulos et al.,., ${ }^{27}$ and Müller et al. ${ }^{35}$

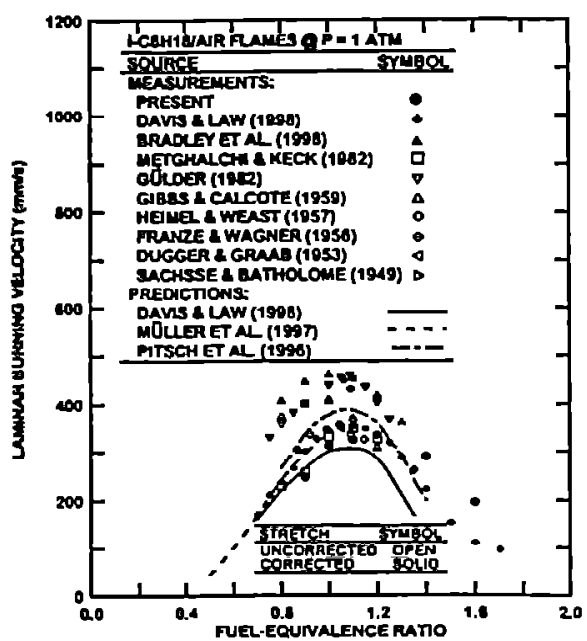

Fig. 8 Measured and predicted laminar buming velocities as a function of Karlovitz number and fuel-equivalence ratio for iso-octane/air flames at STP. Measurements of Sachsse and Bartholome, ${ }^{15}$ Dugger and Graab, ${ }^{17}$ Franze and Wagner, ${ }^{19}$ Heimel and Weast, ${ }^{20}$ Gibbs and Calcote, ${ }^{22}$ Gülder, ${ }^{23}$ Metghalchi and Keck, ${ }^{24}$ Bradley et al., ${ }^{9}$ Davis and Law $^{29}$ and the present investigation; predictions of Davis and Law, ${ }^{29}$ Pitsch et al., ${ }^{33}$ and Müller et al. ${ }^{35}$

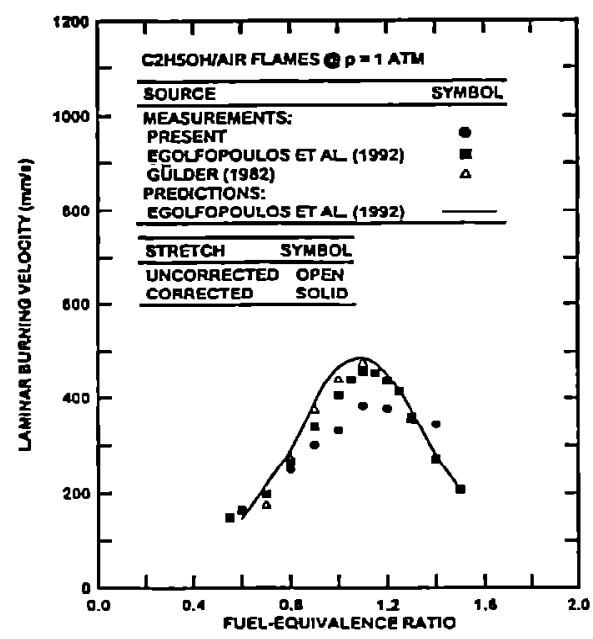

Fig. 10 Measured laminar buming velocities as a function of fuel-equivalence ratio for ethylalcohol/air flames at STP. Measurements of Gülder, ${ }^{23}$ Egolfopoulos et al. ${ }^{28}$ and the present investigation; predictions of Egolfopoulos et al. ${ }^{28}$ 


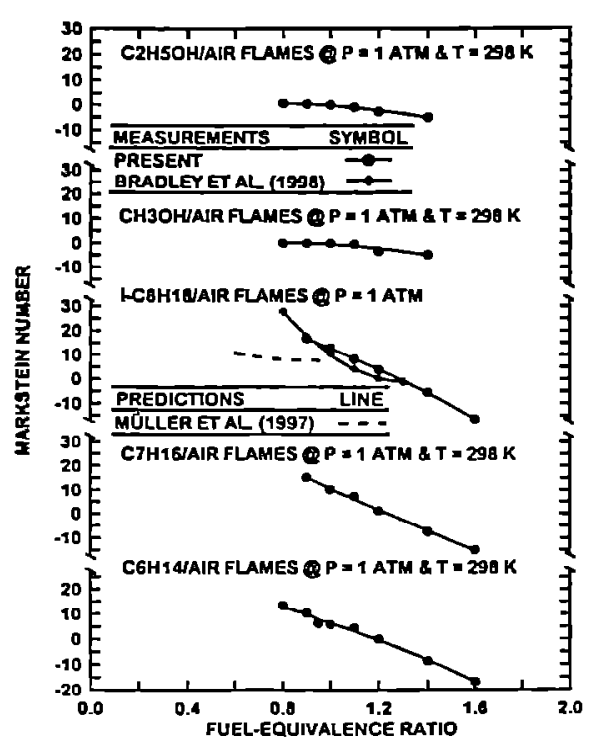

Fig. 11 Measured and predicted Markstein numbers as a function of fuel-equivalence ratio for liquid-fuel/air flames at STP. Measurements of Bradley et al. ${ }^{10}$ and the present investigation; predictions of Müller et al. ${ }^{34}$

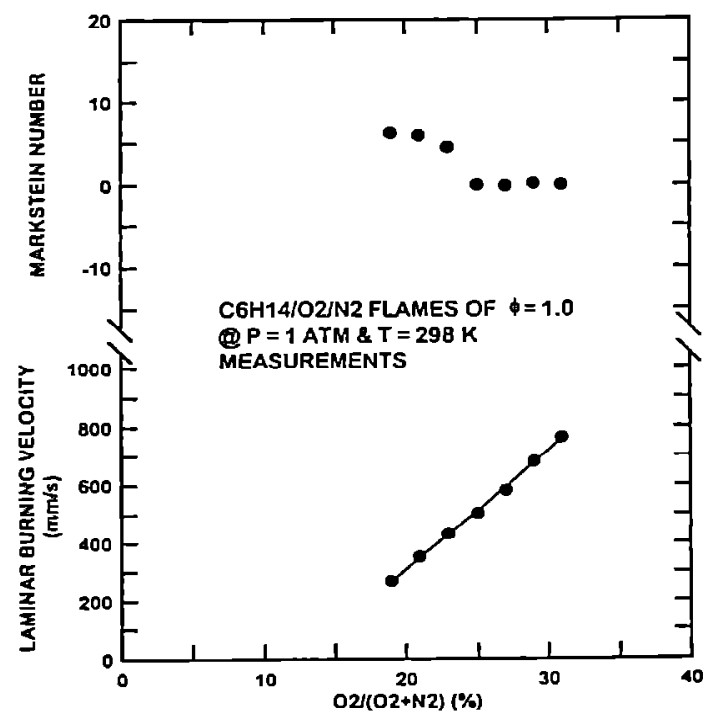

Fig. 13 Effect of oxygen concentration on measured laminar burning velocities and Markstein numbers of $n$-hexane $/ \mathrm{O}_{2} / \mathrm{N}_{2}$ flames at a fuel-equivalence ratio of 1.0 and STP.

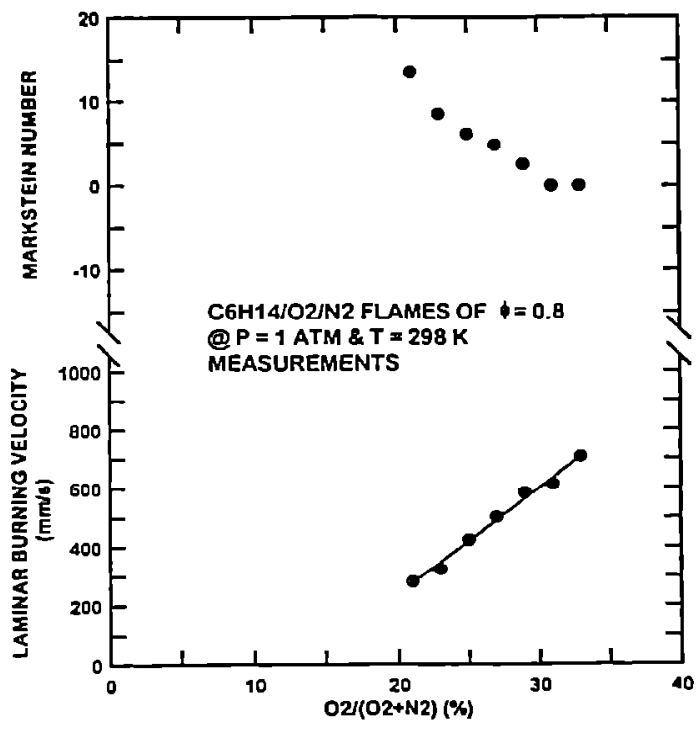

Fig. 12 Effect of oxygen concentration on measured laminar burning velocities and Markstein numbers of $n$-hexane $/ \mathrm{O}_{2} / \mathrm{N}_{2}$ flames at a fuelequivalence ratio of 0.8 and $S T P$.

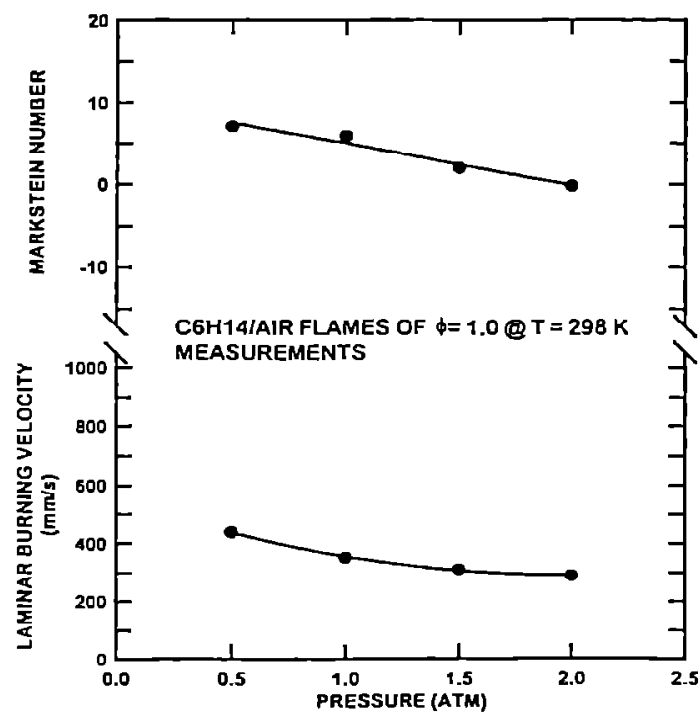

Fig. 14 Effect of pressure on measured laminar burning velocities and Markstein numbers of $\mathbf{n}$ hexane/air flames at a fuel-equivalence ratio of 1.0 and a temperature of $298 \mathrm{~K}$. 